Mansoura Engineering Joumal, (MEJ), Vol. 34, No. 4, December 2009.

\title{
Electrochemical Treatment of Wastewater Containing Cyanide and Zinc
}

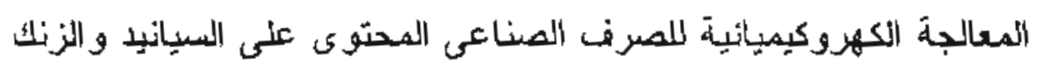

\section{M.Hanafy}

Chemical Engineering Dept., Faculy of Engineering, Cairo University, Giza, Egypt.

$$
\text { الملخص العربي }
$$

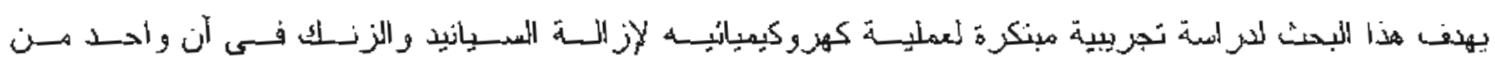

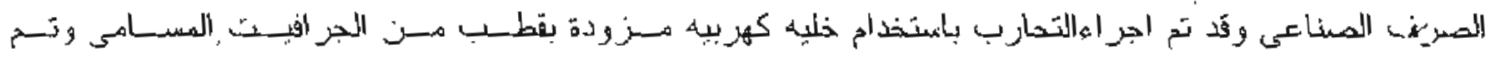

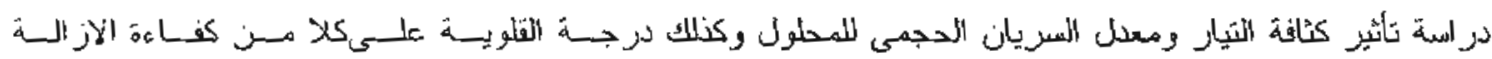

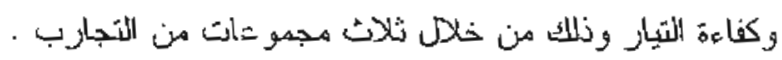

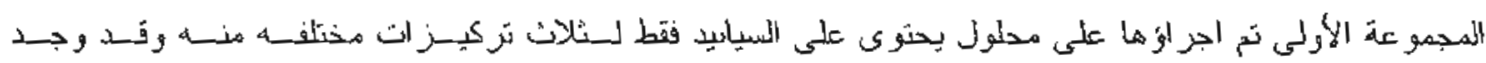

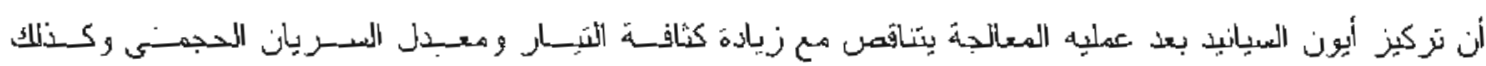

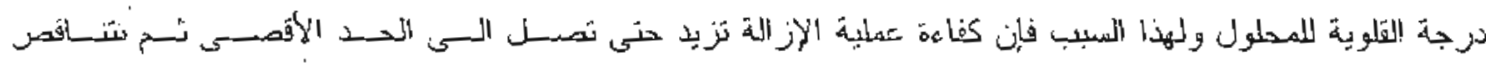

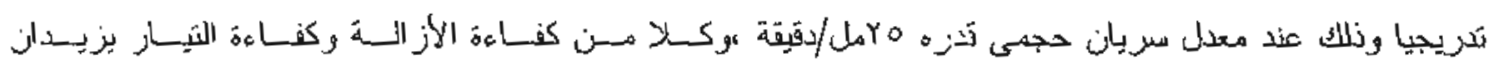

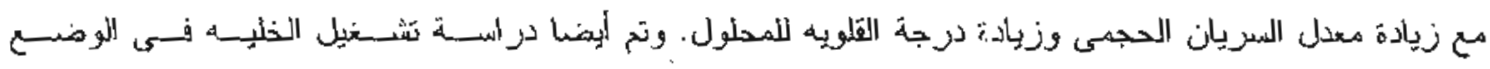

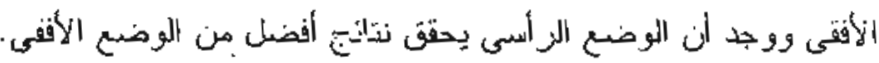

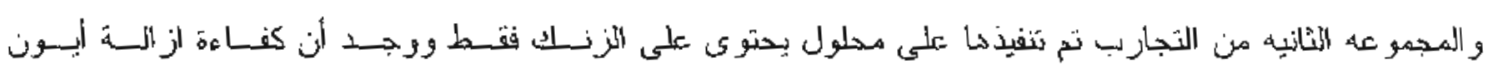

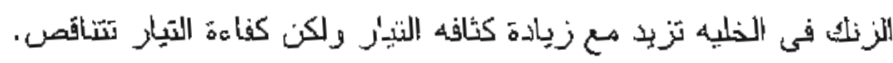

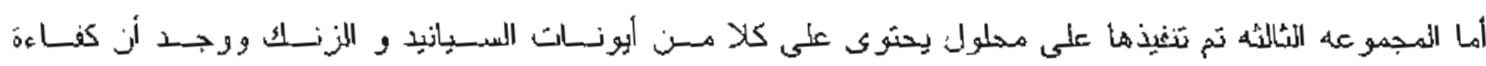

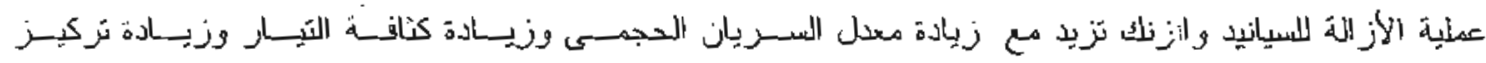

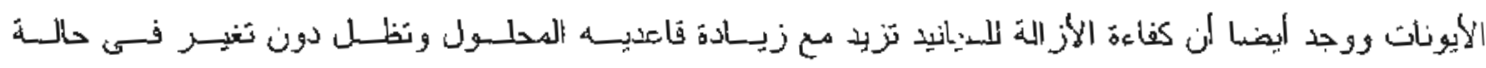

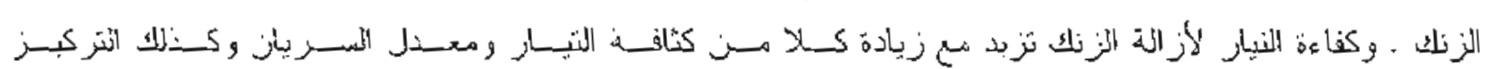

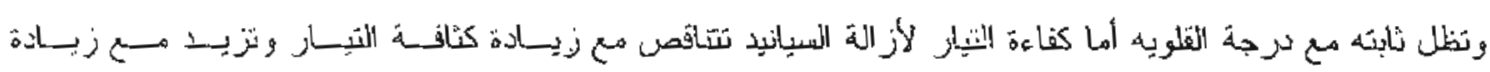

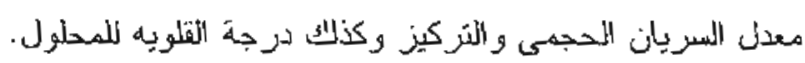

\section{ABSTRACT}

A study was carried out to investigate the feasibility of using a packed bed electrochemical reaclor with tlow-through porous graphice electrodes to iemove either cyanide and/or zino ions simultaneously from wastewater. The effects of cell current density, flow rate, $\mathrm{pH}$ and inlet concentration on removal efficiency and current efficiency of either cyanide ion or zinc jon and combination of both ions removal were studied. It was found that the removal efficiency of cyanide ion increases with cell current densi'y, $\mathrm{pH}$ and feed flow rate. Several cell arrangements were investigated. It was found that the vertical artangement of cell is better than the horizontal arrangement. For zinc renoval it was found that removal chicicney of zinc ion increases with cell curren density. For a combination of both ions it was found that removal efficiencies of zinc and cyanide increase with flow rate, current densily and inic concentration. Current efficiency of zinc removal increases with current, flow rate and zinc ion concentration but remains constant with pH change.

Keywords: Cyanide, anc, electrochemical coll, flow-Ahrough porous electrodes, wasiewater 


\section{INTRODUCTION}

Melal plating has" been identified as an emvirommenally risky industrial sector. The potential bazardous nature of the waste streams often contain high amounts of metals such as nickel, copper, zinc, cbromium as well as cyanide $[1,2]$ Electroplated zinc coatings are widelyused for the protection of cast iron and stee! against corrosion. Alkali-cyanide baths are commonly used. Thus, cyanide complexes with zinc often occur in the plating rinsewater dispensed from electroplating plants. The effluent also contains acidic and alkaline rinses, spent baths and solutions, accidentally spilled liquids, and rinse walers[3,4]. Minimizing the environmental impact of the metal plating activity can best be achieved by the adoption of pollution prevention, pretreatment and cleaner production methods prior to final effluent Ireatment $[5,6.7]$ In addition, the remaining wasle can be further treated by conventional methods such as chemical precipitation $[8,9,10,11,12,13]$.

Cyanide and zinc ions are considered poisonous substances which pollute water and which need recovery, removal or destruction $[14,15]$. Several ireatment processes are available for cyanide removal using chlorine, ozone, and hypochlorite and hydrogen peroxide [15]. Cyanide can be treated by conversion to carbon dioxide and nitrogen through alkaline chlorination [4.16.17]. This process was carried out in iwo steps: First, cyanide is changed to cyanate at $\mathrm{pH} 10.5-11$, using calcium hydroxide to raise the $\mathrm{pH}$. The reaction requires 60 min for $100 \%$ completion. Second, chlorination at $\mathrm{pH} 8$ was made to convert the cyanate into nitrogen and carbon dioxide gases. The latter reaction requires 1 h to complete. The complete conversion of cyanate was carried out by a careful reduction of $\mathrm{pH}$-value from 11 to 8 in the presence of excess chlorine. Cyanide mus! be pretreated not only to meet disposal requirements. but also because it acts as a complexing agent hat indibils precipitalion $[18,19]$. Zinc can also be deposited with ferric chloride, aluminum sulfate, powdered $\&$ granular activated carbon and by using chlorination used in conjunction with coagulation and filtration through sand filter [20].

Electrochemical method obviates the use of dangerous chemicals and the formation of toxic volatile compounds containing chlorinewhen using alkaline chlorinaticn. Chemical methods suffer the drawback of generating a large quantity of sludge. which contains heavy metal after chemical decomposition and the electrochemical method, in theory, has the advantage of decomposing cyanide at the anode and collecting heavy metal at the cathode simultaneously without generation of sludge[21]. Socha et al [22] sludy the electrochemical oxidation of dilute solutions containing cyanide complexes of zinc using a carbon felt anode. The composition of the solution was determined using stability constants for particular complexes. The application of a carbon felt electrode enables the oxidation of cyanides $(10 \mathrm{mmol} d \mathrm{~m}-3)$ in $99.2 \%$ at $0.7 \mathrm{~V}$. Under these conditions, the electrical energy consumption is about $24 \mathrm{kWh}$. Modification of the anode surface with copper oxides allows a cyanide conversion degree of $99.6 \%$ at $0.7 \mathrm{~V}$ with electricsl energy consumption of $17.6 \mathrm{kWh}$. In this article, a novel process is investigated in which both cyanide is oxidized and removed at the anode of an electrolyzer and zinc is deposited at the cathode.

Tamura et al [23] found that the mechanism of cyanide oxidation at the anode is as follows:

$$
\begin{aligned}
& \mathrm{CN}^{-}+2 \mathrm{OH}^{-} \longrightarrow \mathrm{CNO}^{-}+\mathrm{H}_{2} \mathrm{O}+2 \mathrm{e}^{-}(1) \\
& 2 \mathrm{CNO}^{-}+4 \mathrm{OH}^{-} \longrightarrow 2 \mathrm{CO}_{2}+\mathrm{N}_{2}+2 \mathrm{H}_{2} \mathrm{O}+6 \mathrm{e}^{-}(2) \\
& \mathrm{CNO}^{-}+2 \mathrm{H}_{2} \mathrm{O} \longrightarrow \mathrm{NH}_{4}^{+}+\mathrm{CO}_{3}^{--}(3)
\end{aligned}
$$

Hine et al [24] found that "with pbO2 coated electrodes, the current density and temperature do not affect the current 
efficiency". However the current efficiency does drop significantly when the cyanide concentration is below $0.2 \mathrm{M}$. Tissot and Fragniere $[25]$ found that the detailed mechanism of the reaction is still Controversial, but it has been generally accepted that the first step of the electrochenical oxidation of cyanide is as shown previously in equation (1). This reacrion is slow on platinum and graphite and on more active anodes like stainless sleel, magnetite or lead. Electro deposited lead dioxide on titanium or stainless steel seems to be a good compromise between a good efficiency and acceptable corrosion resistance. Kuhn [26] said that in particular that cyanide was oxidized on platinum without oxygen evolution. There appear to be at least two reaction mechanism for its formation one being alkali catalyzed polymerization and the other being reaction of cyanogen with alkali or water as follows:

$(\mathrm{CN} 2+2 \mathrm{KOH} \longrightarrow \mathrm{KCN}+\mathrm{KCNO}+\mathrm{H} 2 \mathrm{O}(4)$ Or $(\mathrm{CN}) 2+\mathrm{H} 2 \mathrm{O} \longrightarrow \mathrm{HCN}+\mathrm{HCNO}(5)$

Sawer and Day[27] reported ammonia as an vnidation producl again in lerms of reactions of the cyanogen with the solution. The limited data of Dart et al[28] indicate no diflerence between results obtained on graphite and platinised titanium. Dodge et a) [29]discussed an anodic reaction as follows:

$$
\mathrm{CN}^{-}+\mathrm{OH}^{-} \longrightarrow \mathrm{CNO}^{-}+\mathrm{H}^{+}+\mathrm{e}^{-}(6)
$$

Lure and Genkin [30] also state this reaction to occur, as well as the following reaction:

$2 \mathrm{CNO}^{\circ}+4 \mathrm{OH}^{\circ} \rightarrow 2 \mathrm{CO}_{2}+\mathrm{N}_{2}+2 \mathrm{H}_{2} \mathrm{O}+6 \mathrm{e}^{\circ}(7)$

Easton [31] stated that the following two reactions take place, but Rumi and Topinka[32] found that cyanide converts into ammonia and carbonate

$\mathrm{CN}^{-}+2 \mathrm{OH}^{-} \longrightarrow \mathrm{CNO}^{-}+\mathrm{H}_{2} \mathrm{O}+2 \mathrm{e}^{-}(8)$

and $2 \mathrm{CNO}^{-}+4 \mathrm{OH}^{-} \longrightarrow 2 \mathrm{CO}^{-}+\mathrm{N} 2+2 \mathrm{H} 2 \mathrm{O}(9)$
Christopher et al[33] discussed the system chemistry where the solution of cyanide and its electrochemical oxidation are rather complicated depending on the reaction conditions The reaction products are observed but the primary reaction is converting the cyanide to the much less loxic product, namely, cyanale and the reaction that decreases current efficiency in excess of hydroxide with the evolution of oxygen.

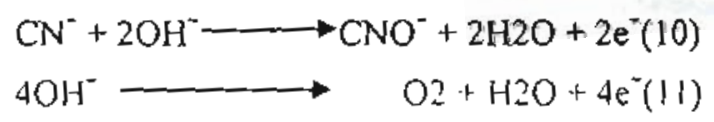

The conversion of cyanide to cyanate exhibits large overpotential but it can be catalyzed by copper. Katagiri et al [34] showed that cuprous ion in a cyanide complex is oxidized anodically and the products are cuperous ion and cyanogen which is hydrolyzed to cyanate and that when the concentration of hydroxide becomes small the anodic reaction must change, in particular, cyanide is oxidized in the one electron process.

$\mathrm{CN}^{-} \longrightarrow 1 / 2 \mathrm{C}_{2} \mathrm{~N}_{2}+\mathrm{e}^{-}(12)$

The cyanogen $\mathrm{C}_{2} \mathrm{~N}_{2}$ thus formed will react rapidly when it encounters hydroxide in solution according to the following reaction:

$\mathrm{C}_{2} \mathrm{~N}_{2}+2 \mathrm{OH}^{-} \longrightarrow \mathrm{CN}^{-}+\mathrm{CNO}^{-}+\mathrm{H}_{2} \mathrm{O}(13)$

When the anolyte and catholyte are mixed, the $\mathrm{pH}$ will rise and any cyanogen appearing in the anolyte will be converted to cyanate.Lanza and Bertazzoli [35] reported that mechanism involving $\mathrm{Zn}^{2+}, \mathrm{Zn}$ and $\mathrm{H}^{+}$ species isas follows:

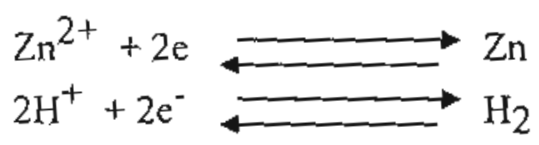




\section{EXPERIMENTAL}

\subsection{Materials}

Alt solutions and suspensions were prepared from $17 \mathrm{M} \Omega / \mathrm{cm}$ resistivity deionized water (Coming, MEGA-PURE System, MP-290, Coming, NY).The Preparation of synthetic solutions was carried out as follows:

\subsubsection{For cyanide ion}

Cyanide solution was prepared by dissolving $2.5 \mathrm{~g}$ of potassium cyanide $99 \%$ purity. in distilled water until completely soluble. This solution was diluted to obtain differen concentrations of cyanide. The experiments were carried out on three solutions:

(A)First solurion containing $1 \mathrm{ppm}$ of cyanide and having $\mathrm{pH}$ of $4.5,5.5,7,9.6$ and 10

(B) Second solution containing $10 \mathrm{ppm}$ cyanide and having pH of $4.5,5.75,7,9.25$ and 10 .

(C) Third solution containing 100 cyanide and having $\mathrm{pH}$ of $3.09,4.5,7,9.76$ and 11 .

\subsubsection{For Zinc ion}

Zinc solution was prepared by dissolving of $1.0 \mathrm{gm}$ of zinc metal $99 \%$ purity in a small amount of $\mathrm{HNO}_{3}$ and boils the mixture in an electric heater to expel the red vapors of nitrogen oxides. then it was diluted with distilled water to give the desirable concentrations .The experiments were carried out on one solution containing $143 \mathrm{ppm}$ of zinc ions.

\subsection{For both xinc and cyanide ions}

The solution contains 2.0 ppm concentration of cyanide and also $5.4 \mathrm{ppm}$ concentration of zinc with $\mathrm{pH}$. of $2.4,6.3$ and $9.6 . \mathrm{pH}$ of solution was adjusted using sulfuric acid and was measured by a $\mathrm{pH}$ meter.

\subsection{Method}

\subsubsection{Cell construction}

A bench scale electrochemical cell was constructed to study the feasibility of simultaneous removal of cyanide and zinc and to give the designer information needed for the design of the industrial-scale cell The cell is shown in Fig. I. It consists of two porous electrodes (stainless steel rod placed in graphite flakes) in a plexiglass cylinder. Each compartment was $16 \mathrm{~cm}$ in diameter and $12 \mathrm{~cm}$ high. The anode compartment was placed above the cathode compartment and the influent enters at the bottom of the cell.

Two plexiglass perforated disks were placed at each compartment to support the graphite flakes. The cell terminals consists of stainless steel rods $1 \mathrm{~cm}$ in diameter and $10 \mathrm{~cm}$ long which were connected to a $D C$ power supply. Perfect tightness was necessary to prevent leakage and to ensure good electrical contact between electrodes and current collectors. This was achieved by compression using four extemal screws of tie rods and nuts located on the two plates and plexi-glass covered the two cell conpartments. The treated effluent leaves through an opening at the top of the cell. The electrical circuit used in this work is shown in Fig (2). Potential and current are measured between cathode and anode. The cell was connected to a DC power supply conducted between anode and cathode.

Two types of power supplies were used throughout this work, one for potentials up to $30 \mathrm{~V}$ and currents up to $3 \mathrm{~A}$ of type (Manacor PS. 303) and the other consisted of home- made rectifier capable of supplying potentials up to $55 \mathrm{~V}$ and currents up to 10A. Both cell potential and current were measured using digital multi-meter of type DTJ530B 


\subsubsection{Experimental procedure}

1.Feed solution was fed to the cell by gravity from an overhead tank with controlled flow rate using needle valve.

2-Effluent samples from the anode comparment were collected. and were translerred into a dark refrigerator for 24 houss a prevent lise deconposition of cyanide or zinc.

3-The current and potential of the cell were measured after reaching steady-state.

4. For each run, 16 samples of effluent strean were collected at ten minutes intervals and also 12 samples were collected every fifteen minutes afterwards.

5- Each run was stopped after reaching steady state conditions (when constant concentration for zinc or cyanide was sblained).

\subsection{Measurements}

All samples were diluted as needed by adding de-ionized water before analysis. $\mathrm{CN}$ - ions concentration was analyzed by colorimetry followed the pyridine-barbituric acid procedure as described in standard methods. The color was measured by using a UV-visible spectrophotometer (HP8452A, Germany) at a wavelength of $578 \mathrm{~nm}$. The zinc concentration in effluent streams was determined with Nanocolor meter the MACHEREY-NAGEL. GmbH \&Co. KE Posttach 101352-D-52313 DUEREN

\section{RESULTS AND DLSCUSSIONS}

3.1. Effect of operating conditions on the outlet concentration, removal efficiency and current efficiency of cyanide ion alone:

\subsubsection{Effect of current density}

The effect of current density (the ratio between cell current and the geometric cross sectional area of the cell) on the outlet concentration of cyanide is shown in Fig.3. These values are the steady state concentsations reached at different times.. It generalty took around 2 hrs to reach steady state. Fig 4 shows the effect of current density on the removal efficiency for feed concentrations of $1 \mathrm{ppm}, 10 \mathrm{ppm}$ and 100 ppm respectively. All runs conducted at a flow rate of $20 \mathrm{ml} / \mathrm{min}$ and $\mathrm{pH}$ of 9.8 . The removal efficiency (the ratio between the amounts of cyanide oxidized in the cell to the total amount of cyanide fed to the electrolytic cell') increased with an increase in current density. This increase is due to the increased electrode reaction rates and agrees with the results of Ho et al [21] who used stainless steel fibers as electrode materials.

Current efficiency of cyanide removed is defined as the amount of cyanide actually removed divided by the theoretical amount, which should have been removed according to Faraday s law. Fig 5 shows the effect of cell current density on the current efficiency lor I ppm, 10 pprn and 100 ppn injet concentrations The current efficiency decreases with current density due to increase in oxygen evolution

\subsubsection{Effect of flow rate}

The effect of flow rate on the outlet concentration of cyanide is shown in Fig 6.All runs were conducted at pHvalue of 9.8. Also Fig (7) shows that the removal efficiency increases with flow rate because the mass transfer coefficient and its rate increases. It was found that the removal efficiency reaches a maximum at $20 \mathrm{ml} / \mathrm{min}$. and then decreases due to the decrease in residence time inside the anode comartment. Fig 8 shows that the current efficiency increases with flow rate at a constant current density This is due to the increase of mass transfer rates increase with flow rate increase.

\subsubsection{Effect of $\mathrm{pH}$}

The effect of $\mathrm{pH}$ on the outlet concentration of cyanide is shown in Figs 
9\&10 which show that the removal clliciculy imeruses with pll for inlet concentrations of 1,10 and $100 \mathrm{ppm}$. This agrees with Tamura et al [23] who found that the anodic oxidation of cyanide is proportional to the alkalinity of the electrolyte. In strong alkaline solutions, the formation of hydrogen cyanide is prevented and minimal anode gassing is observed, Sawer and Day [27] found that only cyanide ion is electroactive and that the undissociated acid is inert. They concluded that the rate of anodic oxidation is faster at higherr $\mathrm{pH}$. In the lower $\mathrm{pH}$ case, a oneelectron oxidation mechanisn is accepted and cy illogen arpears.

At higher $\mathrm{pH}$ levels, the limiting currents increase indicating the occurrence of cyanate formation where cyanogen will react rapidly with hydroxide in solution so the removal efficiency increases. When the hydroxide concentration in the bulk solution becomes very low, the limiting current density indicates cyanogen formation. Fig 11 Shows that the current efficiency increases with increase in $\mathrm{pH}$ because the anolyte and catholyte are mixed, the $\mathrm{pH}$ will rise and any cyanogen appearing in the inofite will be converted to cyanate so current elficiency increases provided that no other side reactions occur at the anode. These experiments were conducted at a flow rate of $20 \mathrm{~m} / \mathrm{min}$.

\subsubsection{Effect of cell arrangement;}

Fig 12 shows that the vertical arrangement is better than the horizontal arrangement. It is observed that; in the horizontal arrangement the gases accumulate in the cell and it is difficult for gases to go out easily.

3.2. Effect of current density on the outlet concentration, removal efficiency and current efficiency of Zinc ion alone

The effect of current density on outlet concentration of zinc is shown in Fig 13. These are the steady state concentration reached at different times. The approach to steady state takes around 2 hrs. Fig 14 shows that the removal efficiency increases with current density. This increase is due to the increased electrode reaction rates. Fig 15 also shows that the current efficiency decreases with increasing curent density. This is due to the increase of hydrogen evolution as current increases.

3.3. Effect of operating conditions on the outlet concentration, removal efficiency and current efficiency of both zine and cyanide ions:

\subsubsection{Effect of current density:}

Fig 16 shows that the effect of current density on the removal efficiency of cyanide and zinc ions. Removal efficiencies of both cyanide and zinc ions increase with increase in current density. This increase is due to the increase electrode reaction rate. There was no significant change took place for affecting of current density on removal efficiency between each ion alone and both ions with together. This agrees with Ho et al [21] who used stainless steel fibers as electrode materials.Fig 18 shows that the current efficiency of cyanide removal decreases with current density because oxygen evolution increases with current but current efficiency of zinc temoval increases with increase in current density because hydrogen evolution is not significant at these conditions.

\subsubsection{Effect of flow rate}

Fig 17 shows the effect of flow rate on the

removal efficiency of zinc and cyanide where it increases with flow rate because the mass transfer rates for zinc and cyanide ions increase with flow rate This agrees with Lanza and Bertazzoli [35] and agrees with Tissot and Fragniere [25]. There no change took place between the effect of flow rate on moval efficiency for each ion and the effect of flow rate on removal efficiency for both ions. Fig 18 shows that the current efficiency of zino and cyanide removal 
increases with an increase in flow. There was no change between the effect of flow rate on current efficiency for each ion and the effect of flow rate on current efficiency for both ions.

\subsubsection{Fffect of $\mathrm{pH}$}

Fig 19 shows that the removal efficiency of cyanide ion increases with an increase in $\mathrm{pH}$ while no change took place in removal efficiency of zinc ion with $\mathrm{pH}$ increase. For cyanide; at low $\mathrm{pH}$, a one electron uxidalion mechanism is suggested and cyanogen appears. At high $\mathrm{pH}$ levels the limiting current increased indicating the formation of cyanate. No change took place between cyanide ion alone or combination wilh zinc for the effect of $\mathrm{pH}$ on removal elficiency. This agrees with Tamura et al 1231.tor zinc: as lower $\mathrm{pH}$, the limiting curren is higher and removal elliciency increases .As pH increases, a decrease is observed in limiting current and removal efficiency decreases.

\subsubsection{Effect of Inlet concentration:}

Figs 20\&21 show that both removal efficiency and current efficiency of zinc and cyanide increase with concentration increases. This agrees with the findings of Ho et al [21] and Christophers[33].

\section{CONCLUSION}

An electrochemical method was employed in the present study to treat the electroplating wastewater. The effect of $\mathrm{pH}$, current density. flow rate and inlet concentrations were invistigated. The removal efficiency of zinc and cyanide increased with an increase in current density, flow rates and inlet concentration for both ions. The electrochemical method can be used successfully for oxidation and removal of cyanide jons and also the reduction and separation of zinc ions. It is possible to remove cyanide and zinc ions simultaneously at reasonable current and removal efficiencies using the same electrochemical cell.

\section{REFERENCES}

1-Magalha.es, J. A. , Inertization of galvanic sludge by its incorporation in ceramic bodies, Ph.D. Thesis, University of Minho, p. 311,2002.

2-Silva, J. E., Soares, D., Paiva, A. P., Labrincha, J. A., \& Castro, F. , Leaching behaviour of a galvanic sludge in sulphuric acid and ammoniacal media. Joumal of Hazardous Materials, B121, 195-202, 2005.

3-Environmental Protection Agency (EPA). , Profile of the fabricated metal products. Office of Compliance Sector Notebook Project. EPA/310-R-95-007,1995.

4-Christie, W. N. , In industrial waste stream generation. New Jersey; Prentice Hall, 1998.

5-World Bank Group, Pollution prevention and abatement handbook 1998: Toward cleaner production. Washington, D.C: The World Bank Group. 1998.

6-Chang, L. Y. Waste minimization study, chelated complex in wastewater. In: Encyclopedia of chemical processing and design (Vol. 64, pp. 419-439). Marcel Dekker, 1998 .

7-Freeman, H. M. , Industrial pollution prevention. Handbook.New York: McGraw Hill, Inc., 1995.

8-Peters, R. W., Ku, X., \& Bhattacharyya, D. Evaluation of recent treatment techniques for removal of heavy metals from industrial wastewaters. AICHE Symposium Series, Separation of Heavy Metals and Other Contaminants, 81(243), 165-203,1985.

9-Environmental Protection Agency (EPA). - Technical resource document, treatment technologies for metal/cyanide-containing wastes. Hazardous Waste Engineering Research Laboratory, NTIS Order Number PB 38-143896,1987.

10- Patterson, J. W. Metal treatment and recovery. In J. R. Kramer \& H. E. Allen (Eds.), Metal speciation: theory, analysis, and application (pp. 333-345) Chelsea: Lewis Publishers, Inc., 1988. 


\section{P. 8 M. Hanafy}

11-PRC Ënvironnental Management, Inc. (PRC), Hazardous waste reduction in the metal finishing industry. Park Ridge: Noyes Data Corporation, 1989.

12-Abou-Elela, S. I., El-Kamah, H. M.\& E.I-Awady, R. A. Waste minimization in the electroplating industry (case study). The international Journal of Environmental Studies 55, 287-296,1998.

13-Li, Y. J., Zeng, X. P., Liu, Y. F., Yan, S. S.. Hu, Z. H., \& Ni, Y. M., Study on the treatment of copper-electroplating wislewilter by chemical trapping and nocculation. Separation Purification Technology, 31, 91-95,2003.

14- HO.S.P, Wang Y.Y and.Wan C.C, Electrochemical of cyanide with steel fiber Water Research vol 24 No.ll ,p!3!71321.1990.

15-Tissot.P.Fragniere, $M$, Anodic oxidation of cyanide with (R.V.C-Pb02) Journal of Applied Electrochemistry vol.24, p509-512, 1994.

16-Abou-Elela, S. I. ,Treatment of industrial waste water from metal industries (case sudies. Fgypi). Second Egyptian seminar on industrial waste water management, April 4-0. pp y2-1U5. Lairu. Egypi.1993.

17-Wang, L. K., \& Wang, S. M. H. , Handbook of industrial waste treatment (Vol. 1). New York: Marcel Dekker, Inc. 1992.

18-El-Gohary, F. A., Abou El-Ela, S. I., ElKamah. H. M. \& Aly. H. I. . Pollution control of electroplating waslewater (case study). Al-Azhar Engineering Third Intemational Conference, pp. 694$702,1993$.

19-Eckenfelder, W. W. Ir. , Industrial water pollution control. Boston: McGraw Hill. 2000 .

20- Easton.1..Water.pollution.control fed $, 8,1621,1967$.

21- HO.S.P, Wang Y.Y and Wan C.C, Flectrochemical of cyanide with steel fiber, Water Research vol. 24 No.11 pl3!7. 1321.1990.

22- Socha. A, Kusmierek. E and Chrzescijanska. E., Electrochemical treatment of dilute cyanide solutions containing zinc complexes by oxidation at carbon felt ,Journal of applied electrochemistry,vol.32,p409-414,2002.

23- Tamura. H. Arikado. T. Yoneyama. H. and Matsuda. $Y$., Anodic oxidation of potassium cyanide on platinum electrode, Electrochemical Acta, vol.19, p273, 1974.

24-Hine.F. Yasuda M.Lida.T.and Ogata .Y. ,The oxidation of cyanide solutions with lead dioxide coated anode, Electrochemical Acta, vol.31,p1389,1986.

25-Tissot.P, Fragniere. M, Anodic oxidation of cyanide with (R.V.C-Pb02 ), journal of Applied Electrochemistry vol.24,p509512,1994

26- Kuhn.A.T., Electrolytic decomposition in effluent streams, Joumal of Applied Chem Biotechnol, vol.2! February 1971.

27- Sawer. B. T, \& Day. R. J, Electroanalatical Chemistry, vol 5,p195,1963.

28-Dart.M.C.,Gentles.J.Dand Renton. G. D Applied Chem Lond.pl3,55,1963.

29- Dodge ,Reams,Sperry and caldwell, Disposal of Plating room wastes, p 11,1949.

30- Lure.Y.and Genkin, V.E., \&

Soobslich.nanch.rab glclrol, vol 3,p50,1962

31 - Easton.J., Water.pollution.control fed $, 8,1621,1967$.

32- Rumi. V., Topinka.M., metal loberallarhe, vol.22,p225, 1969.

33- Christophers, Fofseth and Thomas W., Electrochemical destruction of dilute cyanide by copper-catalyzed oxidation in a flow through porous electrode, Journal of the Electrochemical Society, vol. 146, p 199-207, 1999.

34- Katagiri.A. et al, Cuperous in cyanide complex is oxidized anodically, Journal of Chermical Society, 1982

35. Lanza .M.R.V and Bertazzoli .R , Removal of zinc from chloride medium using a porous electrode, current penetration within the cathode, Journal of Applied Electrochemistry, vol., 30 p 61 70.2000 
Mansoura Engineering Joumal, (MEJ), Vol. 34, No. 4, December 2009.

P. 9

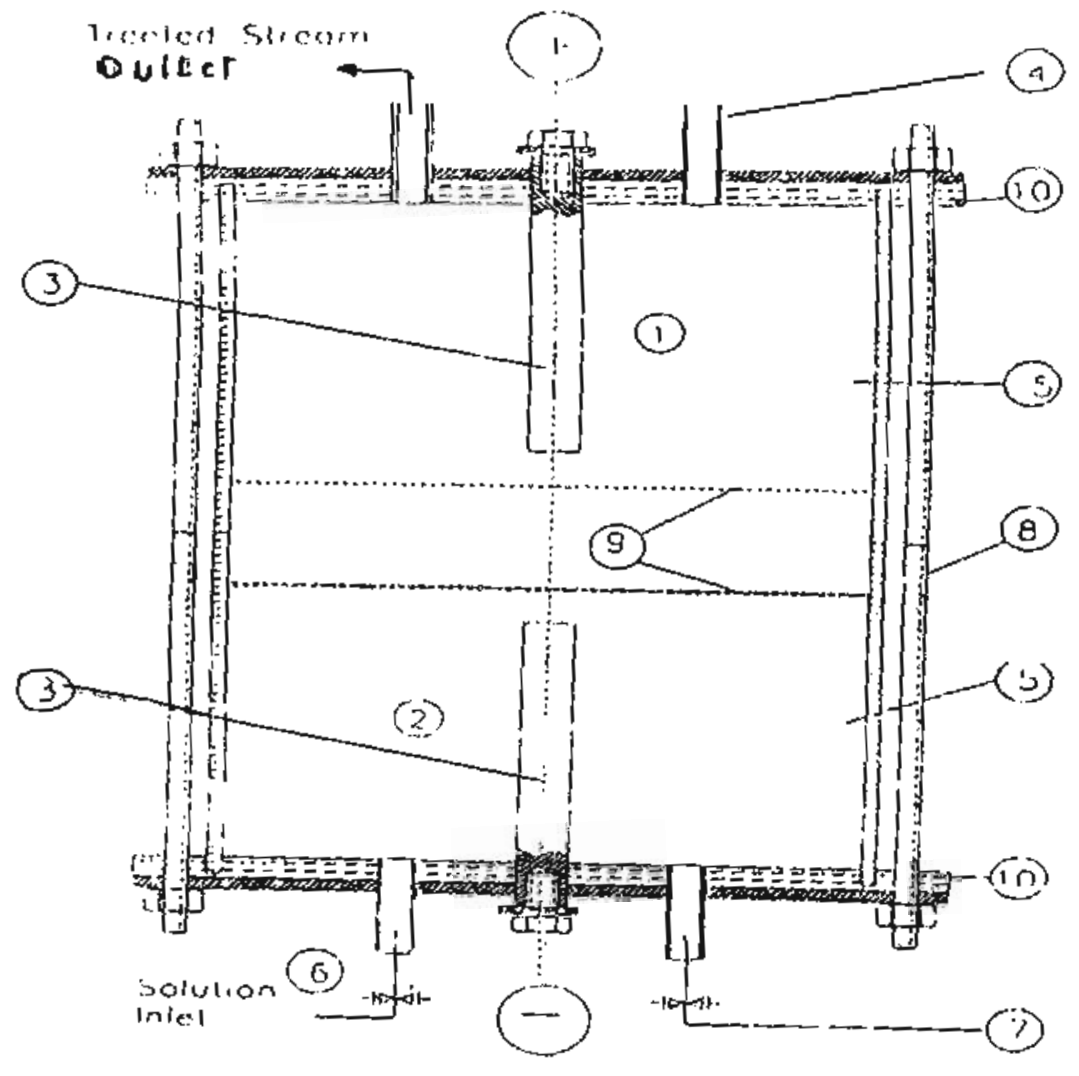
1 - Anode
2- Cathode
3- Stainless steel rods
4- Gas vent
5- Graphic flaks
6- Needle valve
7-Cathode outlet stream
8- Tie rod
9- Plexi-glass perforated disk
10-Plexi-glass cover

Fig I Experimental cell

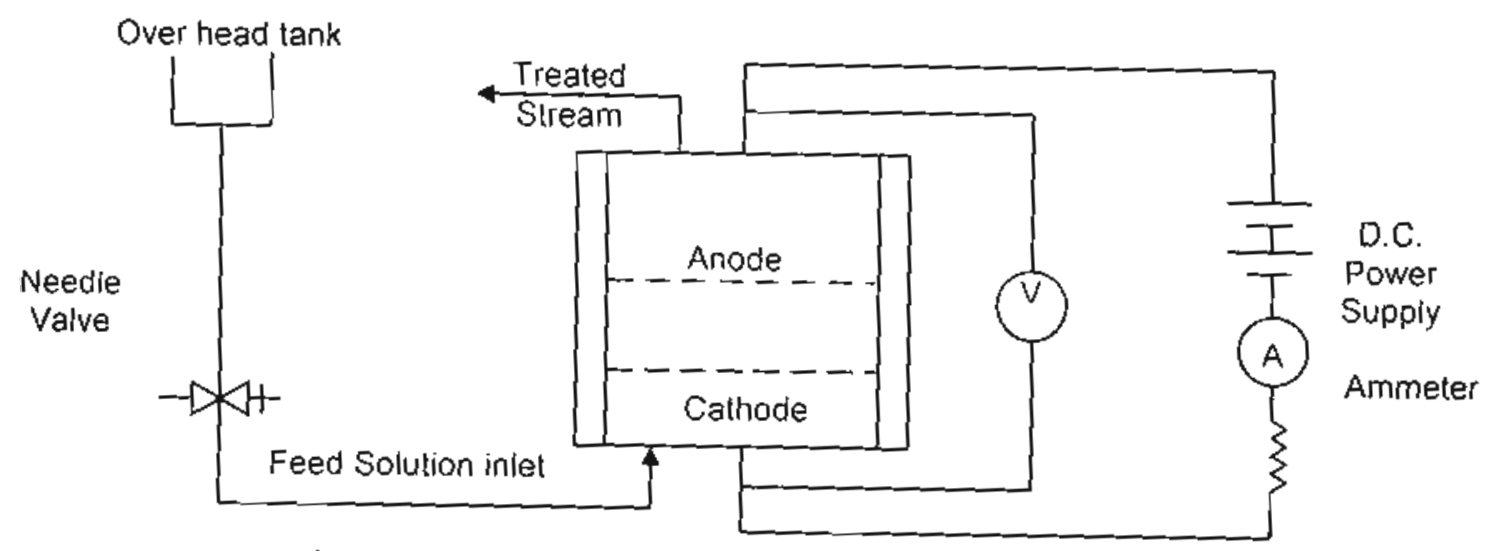

Fig 2 Schematic diagram of experimental apparatus 

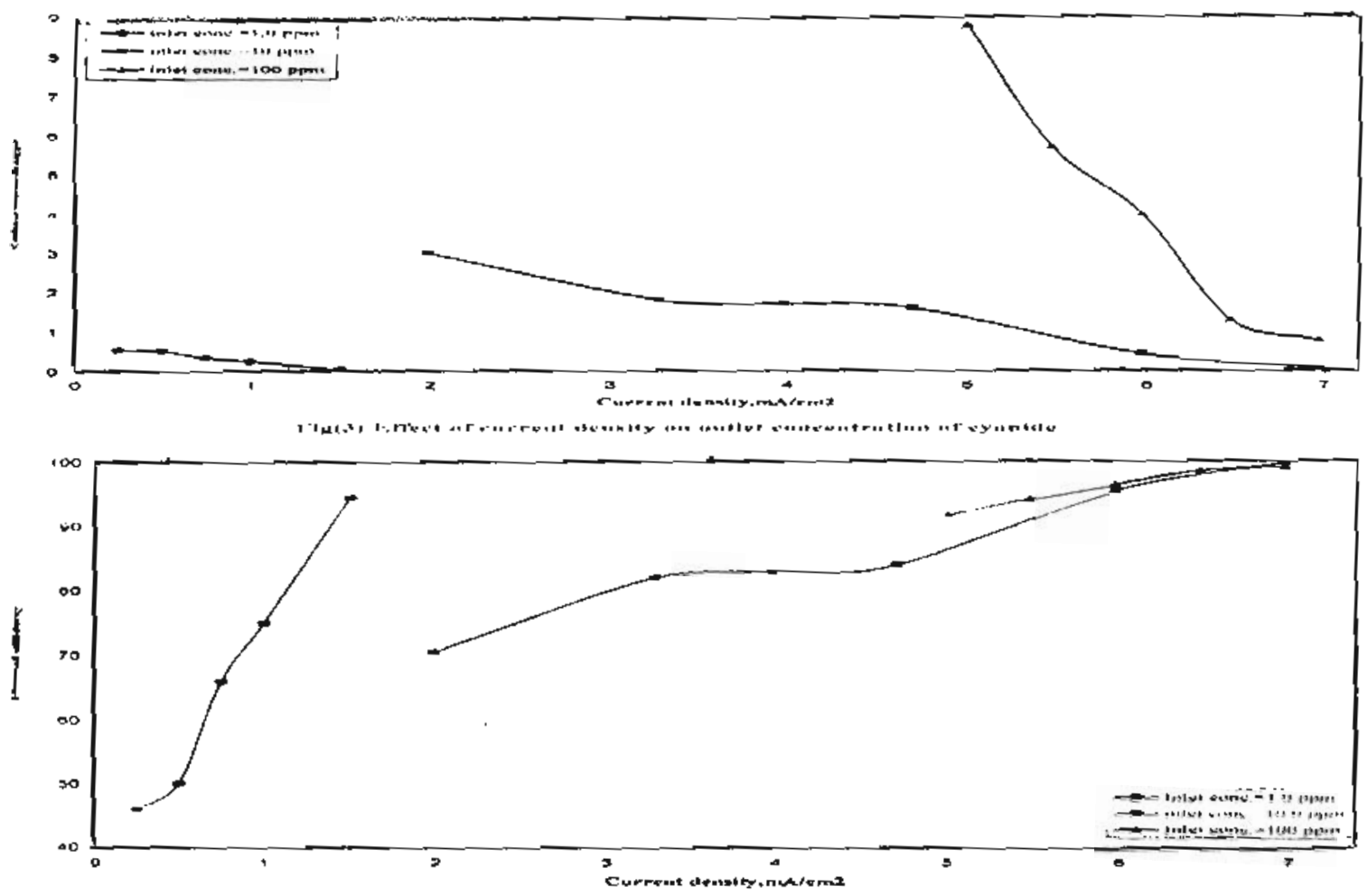

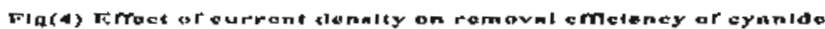

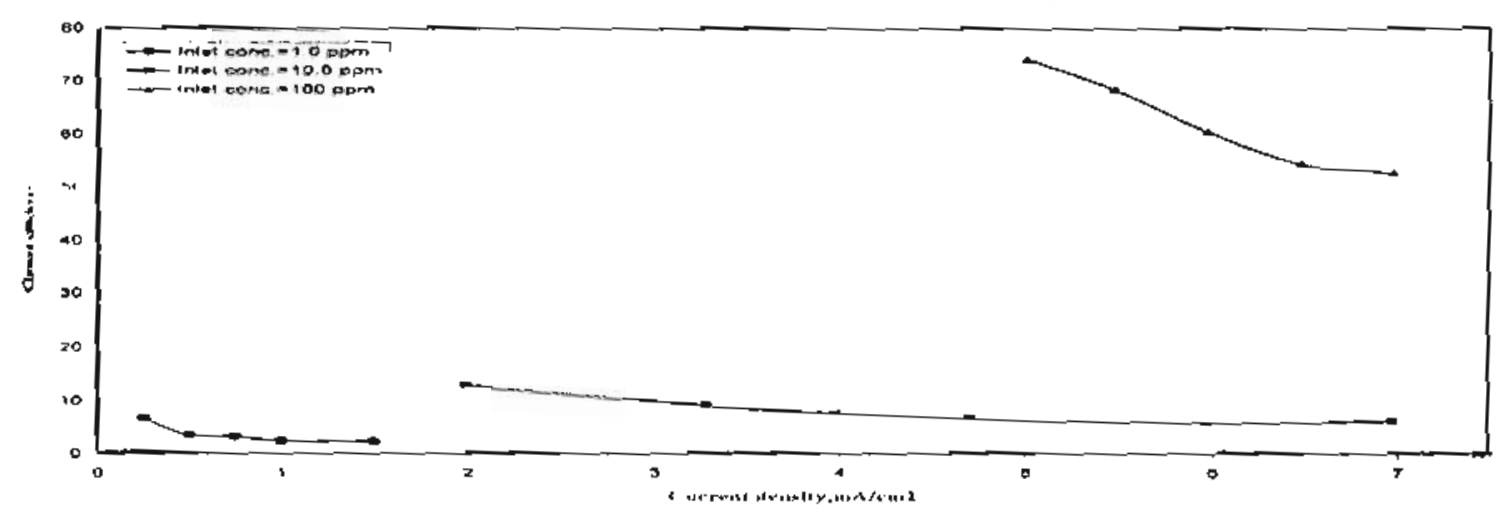

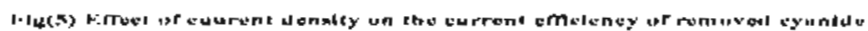

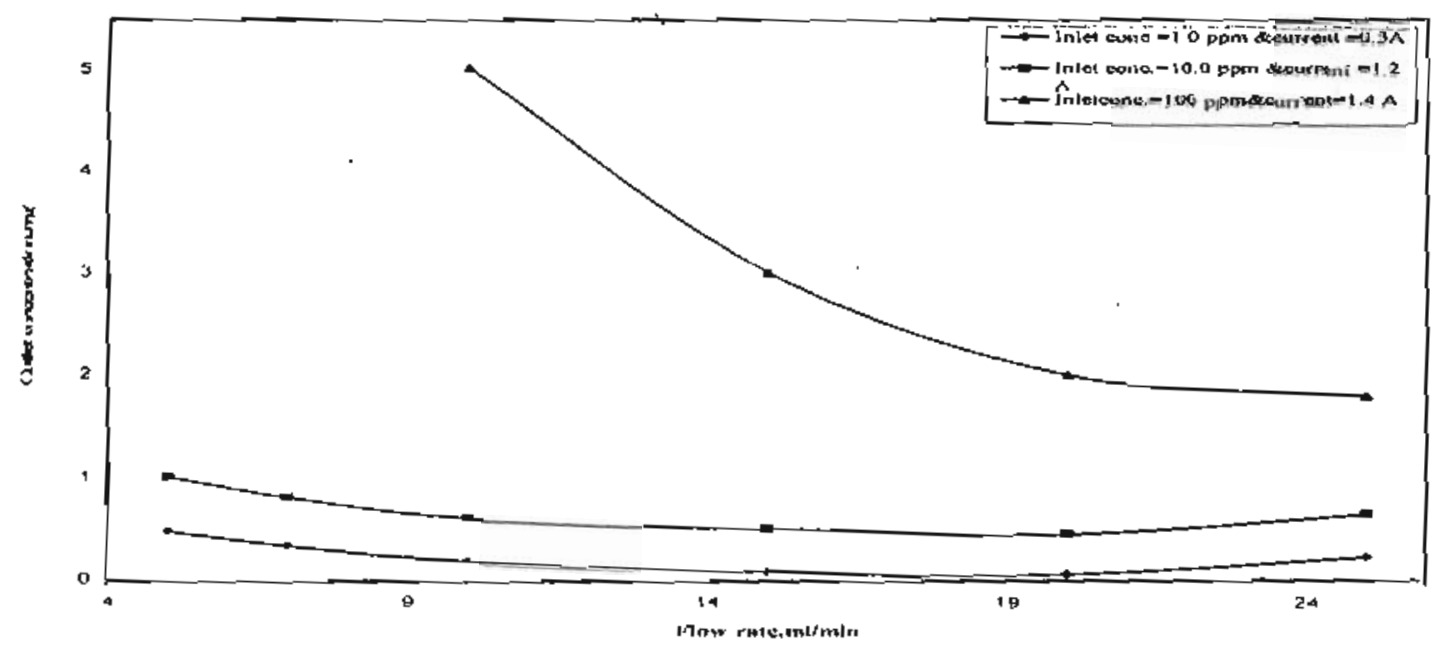

Fig(b) Enect of now l-ate on the outlot conceutratlon of cyanide 
Mansoura Engineering Journal, (MEJ), Vol. 34, No. 4, December 2009.

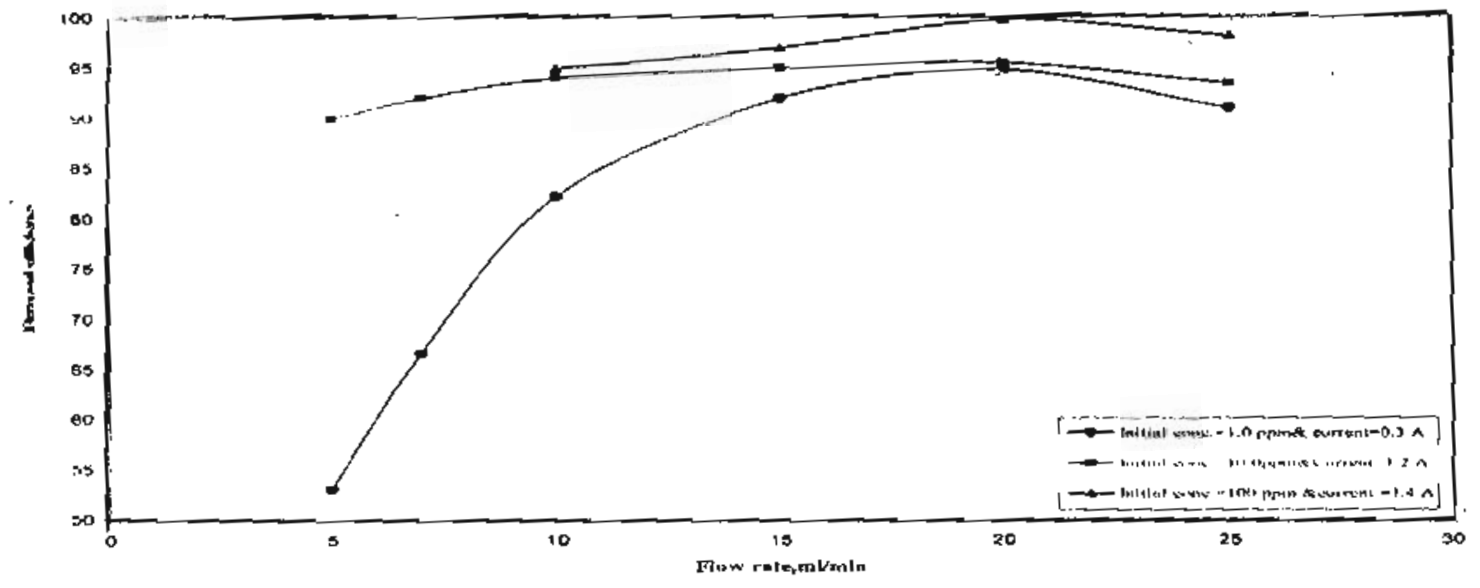

Fie (T) Erret of now mite on the mornd emelency

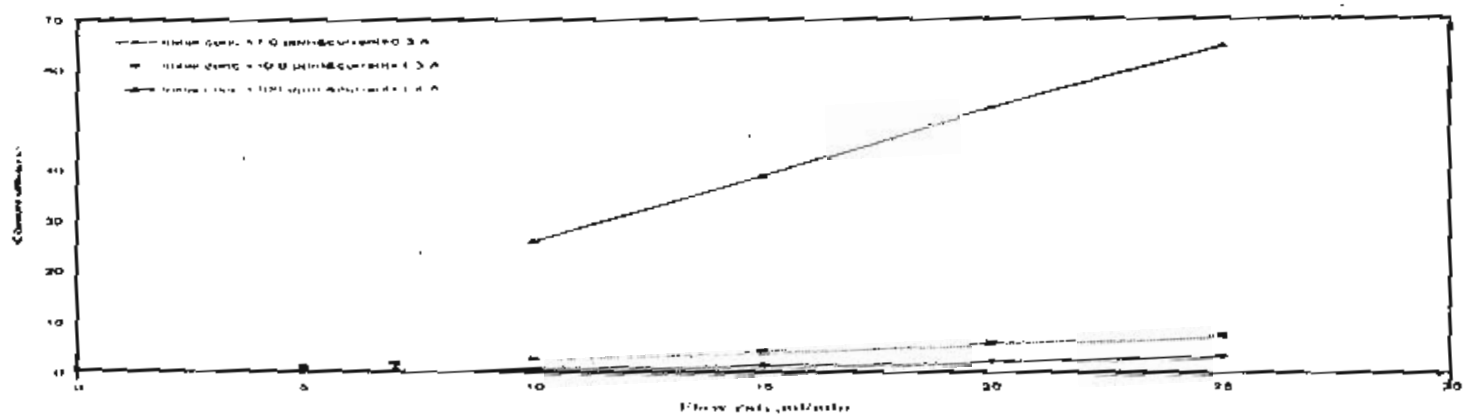

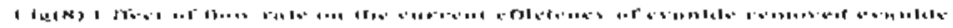
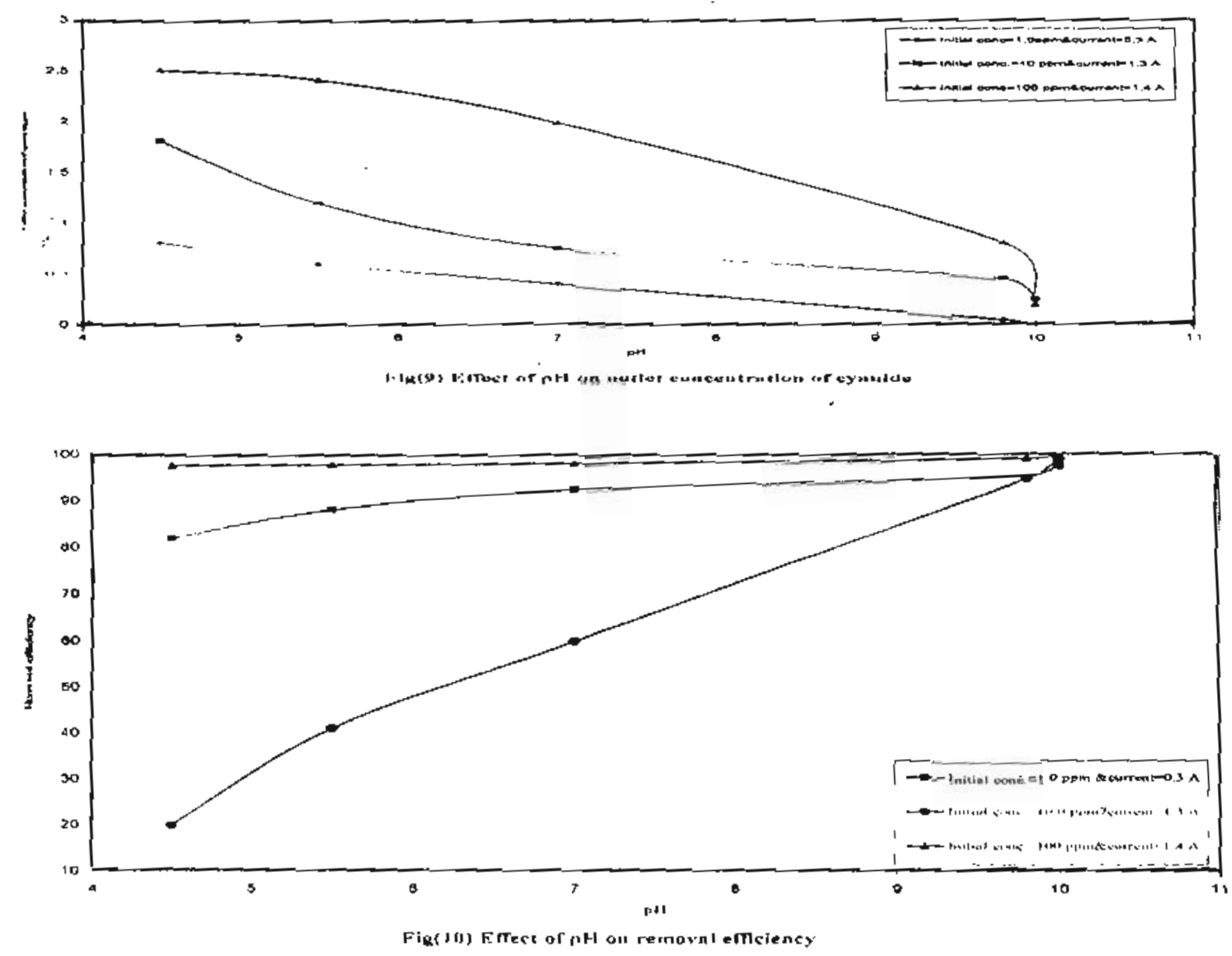


\section{P. 12 M. Hanafy}

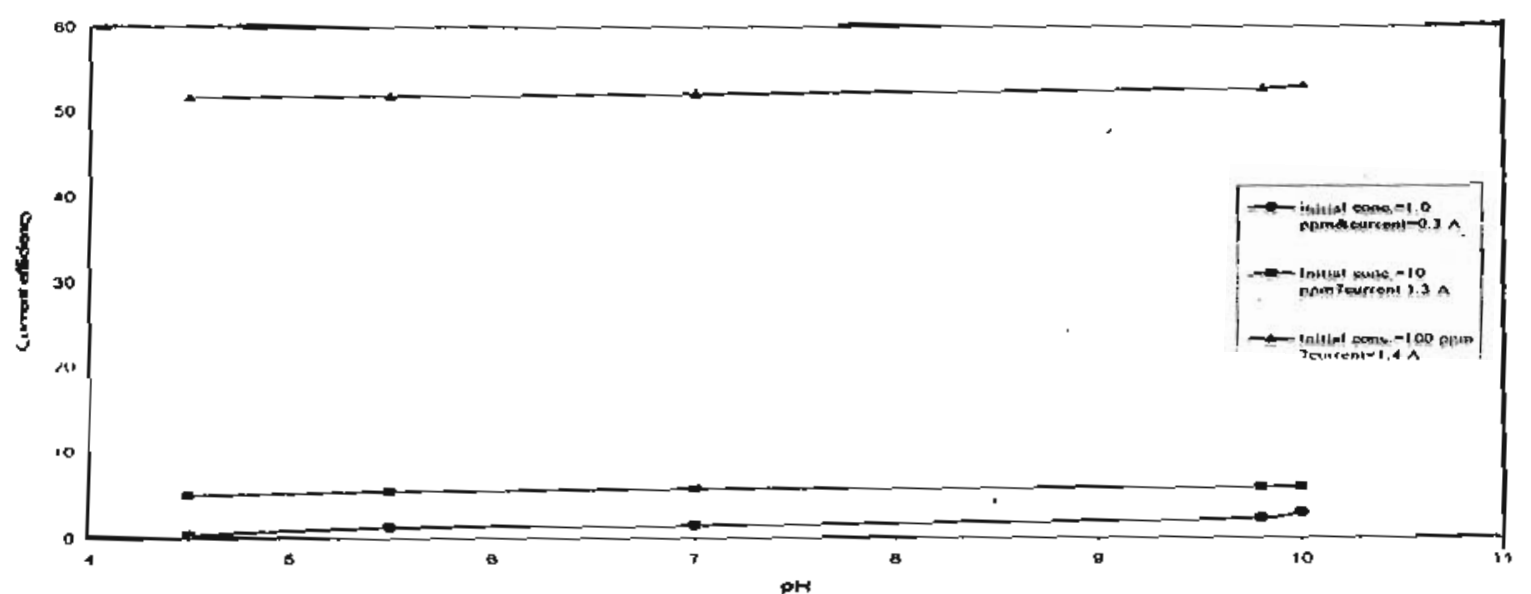

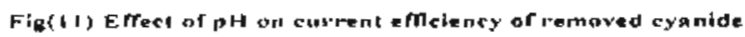

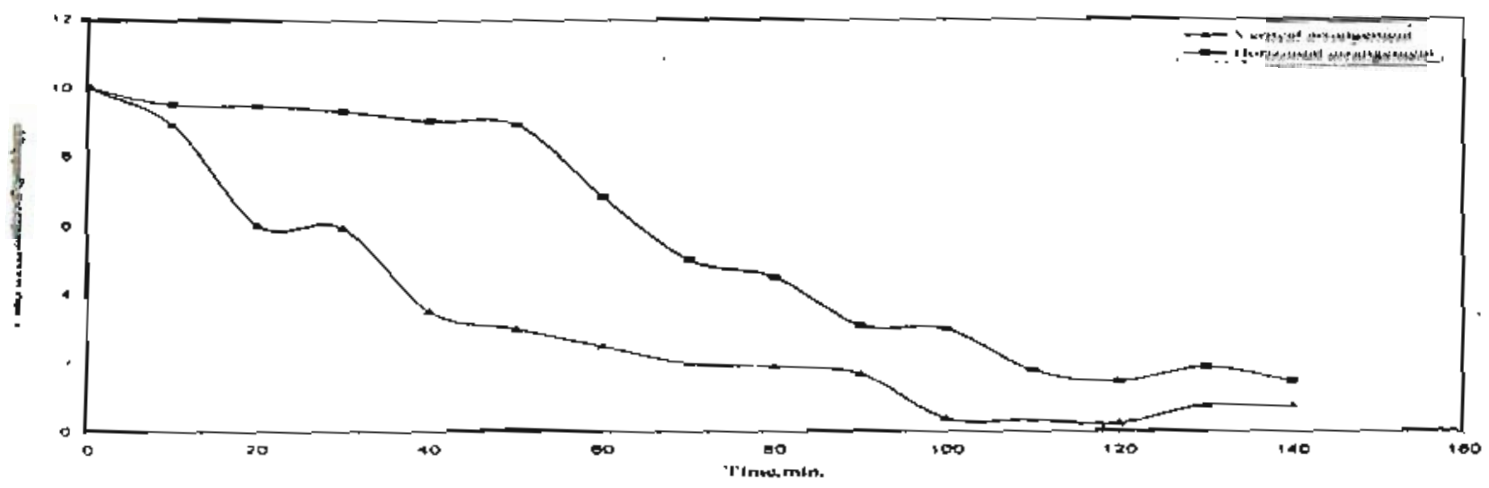

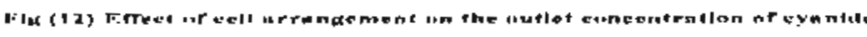

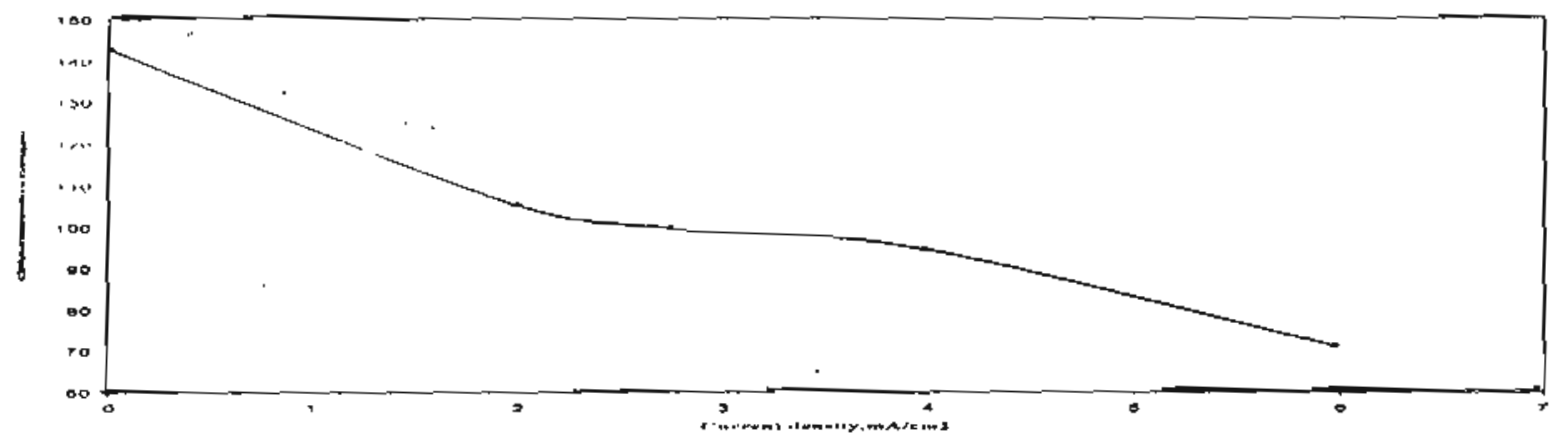

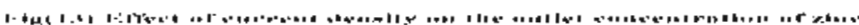

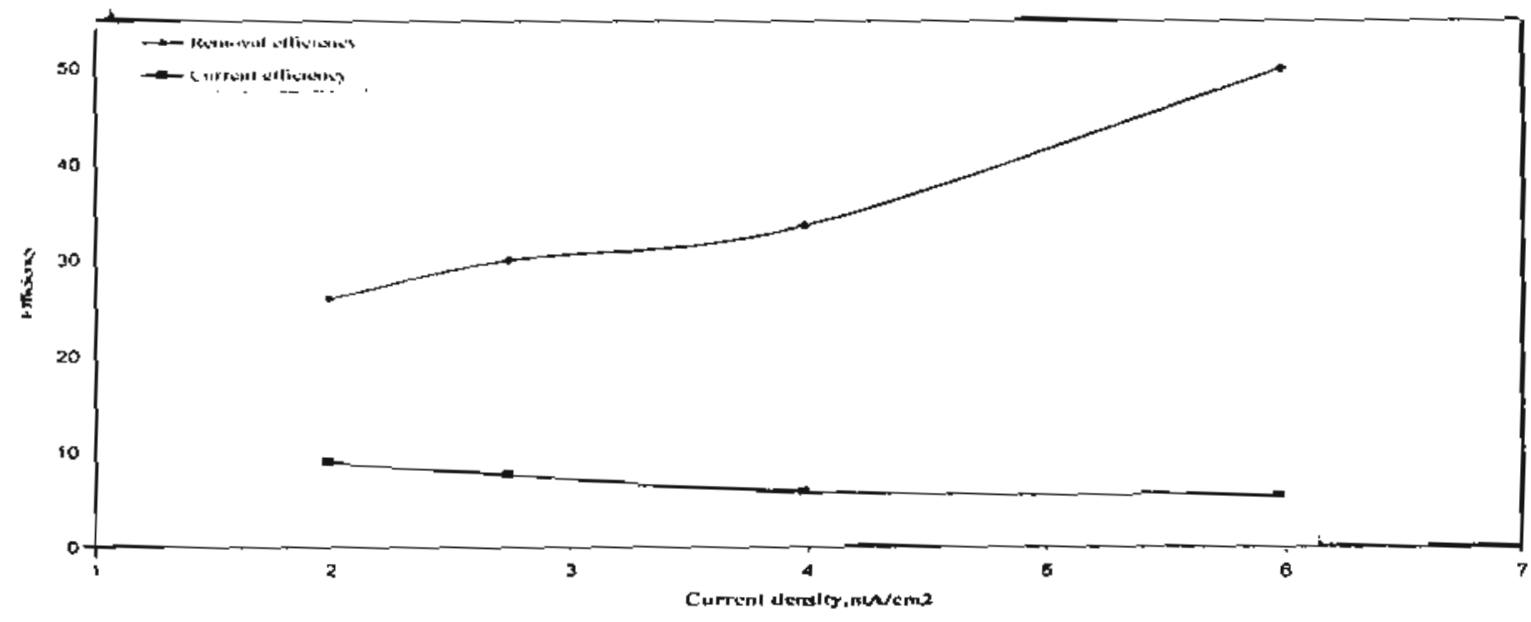

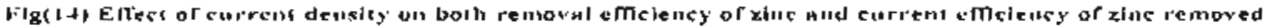




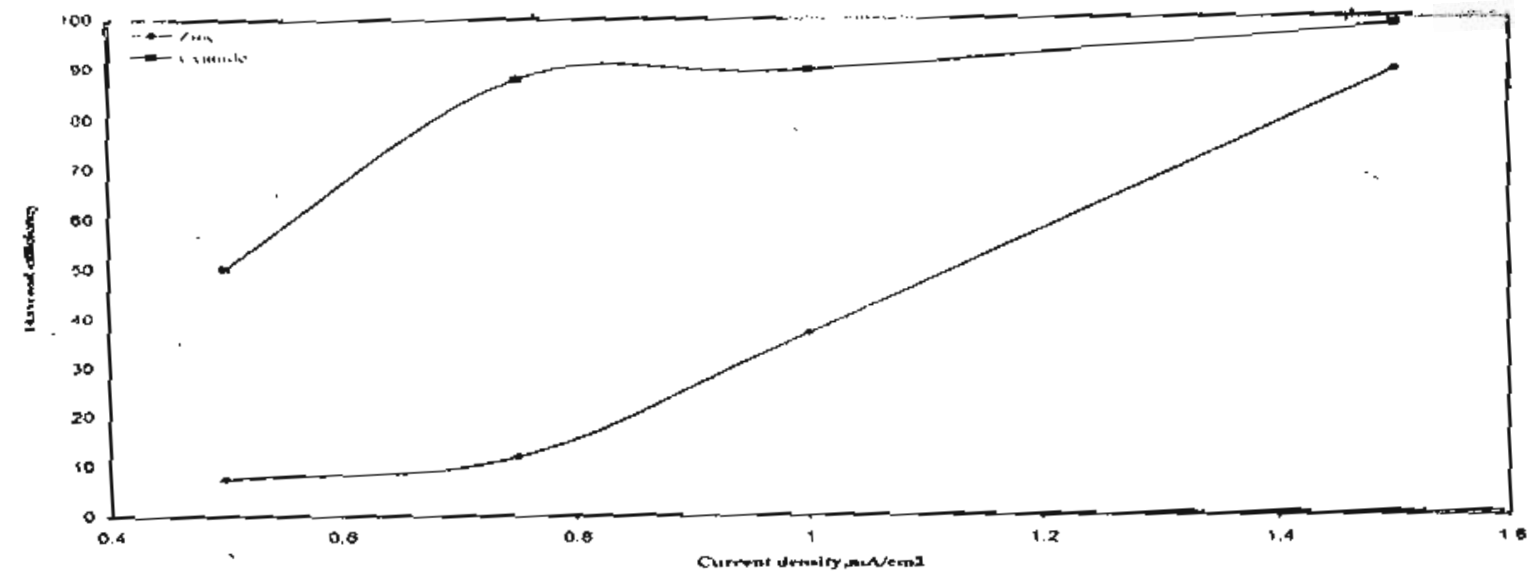

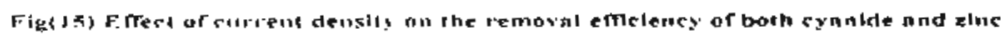
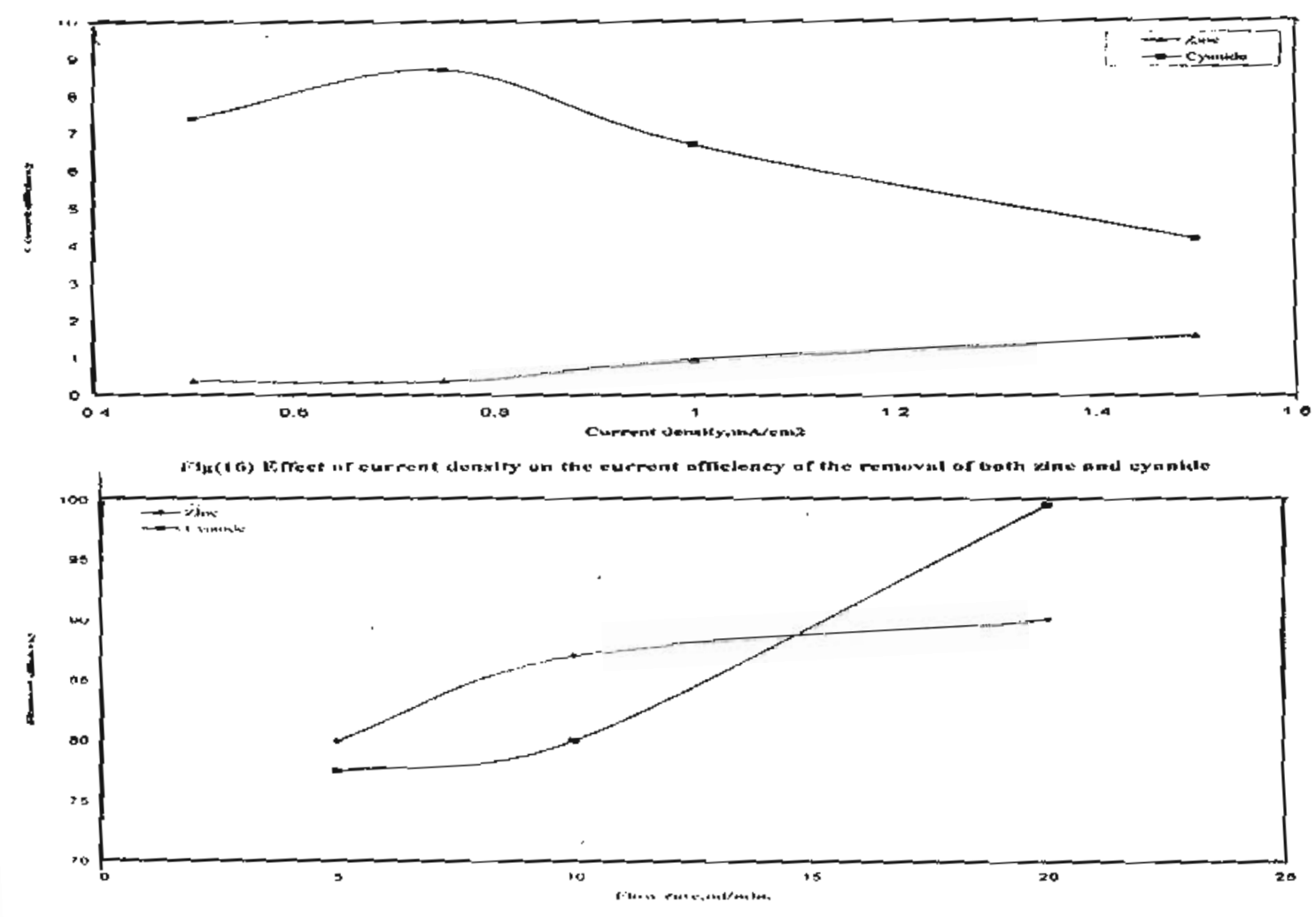

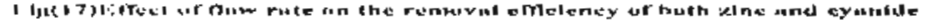

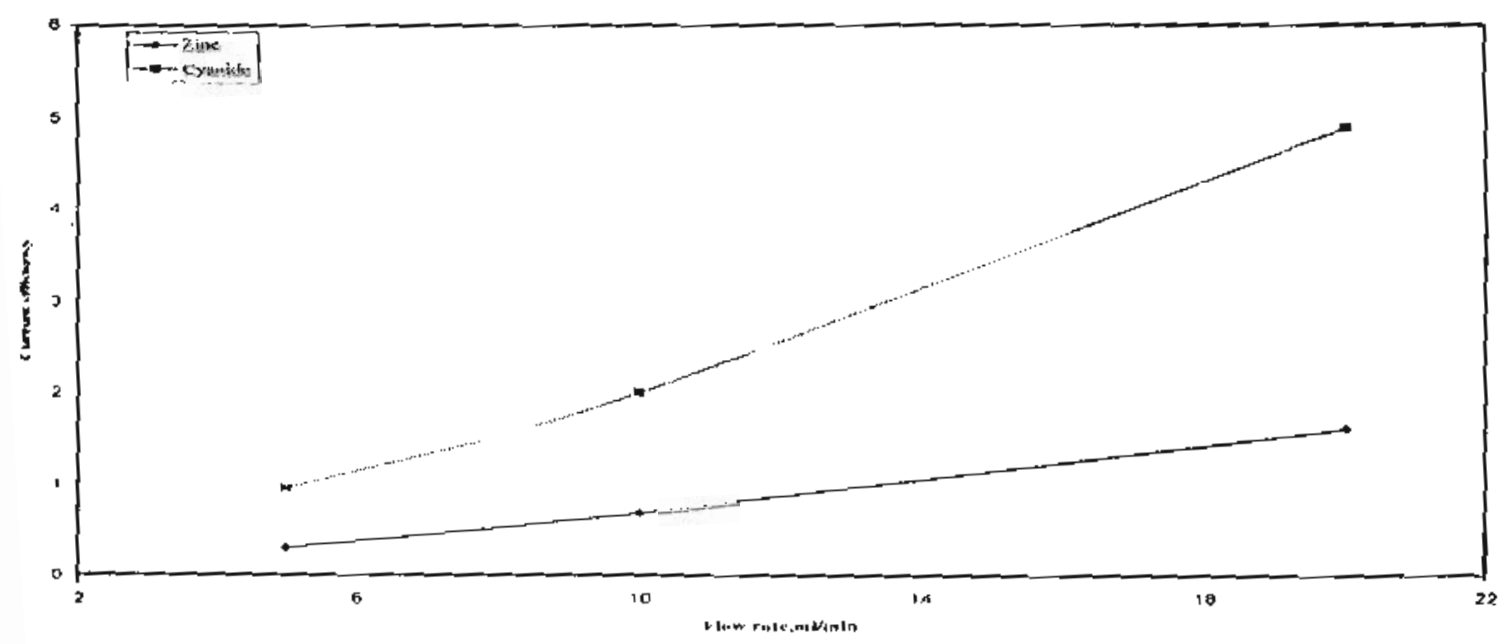

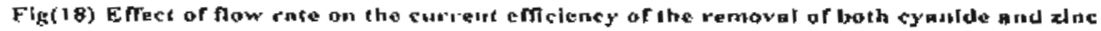




\section{P. 14 M. Hanafy}

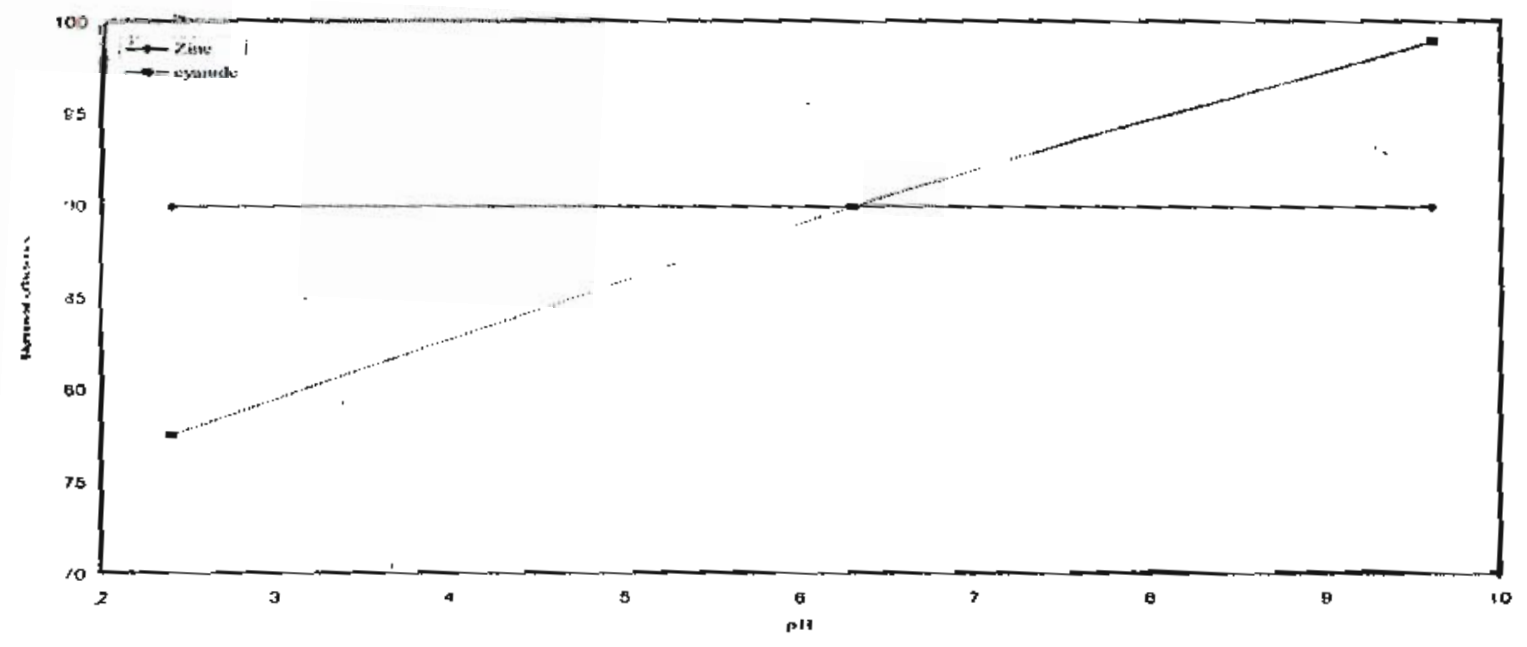

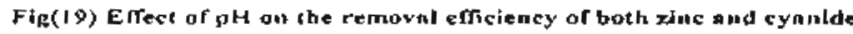

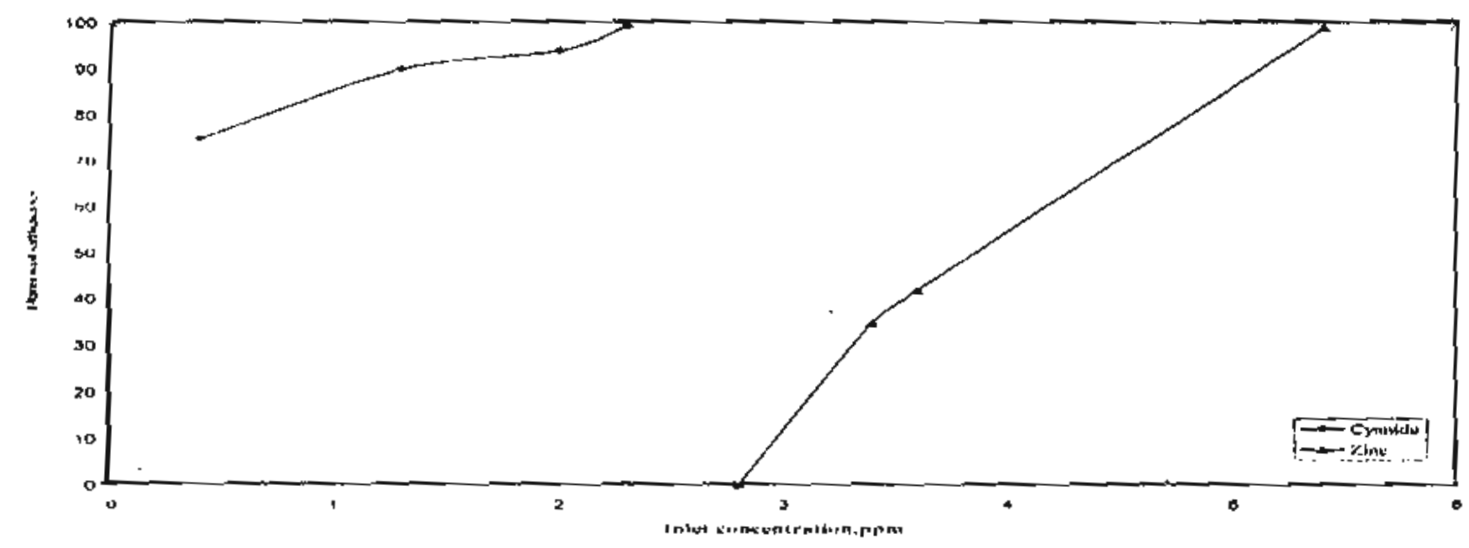

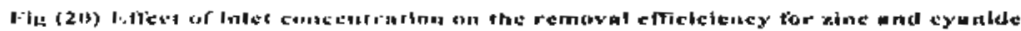

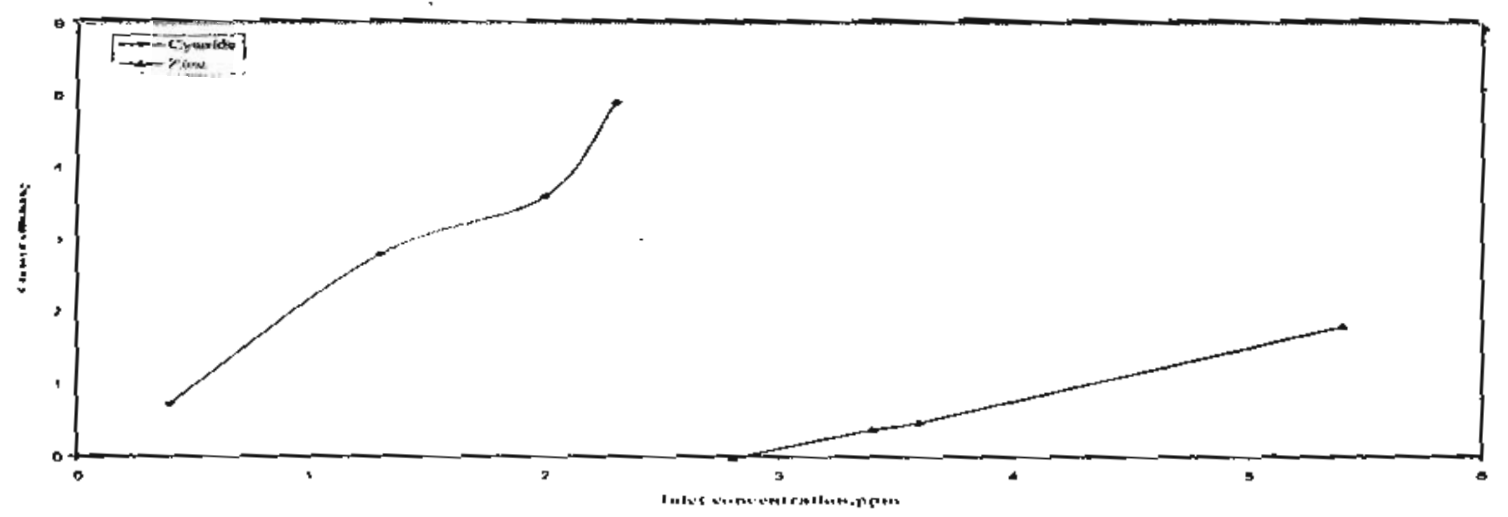

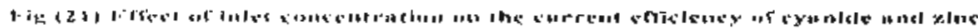

